Envisioning Power 



\section{Envisioning Power}

Ideologies of

Dominance and Crisis

Eric R. Wolf

UNIVERSITY OF CALIFORNIA PRESS

Berkeley / Los Angeles / London 
University of California Press

Berkeley and Los Angeles, California

University of California Press, Ltd.

London, England

(c) I999 by

The Regents of the University of Catifornia

Library of Congress Cataloging-in-Publication Dara

Wolf, Eric R., 1923-

Envisioning power : ideologies of dominance and crisis / Eric. R. Wolt.

$$
\text { p. cm. }
$$

Includes bibliographical references ( $\mathrm{p} . \quad$ ) and index.

ISBN 0-520-21582-6 (alk. paper)

I. Power (Social sciences) 2. Ideology. 3. Kwakiutl Indians.

4. National socialism. S. Aztecs. I. Title.

JC330.W65 1998

$303.3-\mathrm{dc} 2 \mathrm{I}$

Printed in the United States of America

$08 \quad 07 \quad 06$

$\begin{array}{lllllll}9 & 8 & 7 & 6 & 5 & 4 & 3\end{array}$

The paper used in this publication is both acid-free and totally chlorine-free (TCF). It meets the minimum requirements of ANSI/NISO Z39.48-I992 (R 1997) (Permanence of Paper). () 
In wemory of Julius, Rosa, and Kurt Löfler 
